

\title{
Distributional effects of a carbon tax on car fuels in France
}

\author{
Benjamin Bureau
}

\section{To cite this version:}

Benjamin Bureau. Distributional effects of a carbon tax on car fuels in France. Energy Economics, 2011, 33 (1), pp.121-130. 10.1016/j.eneco.2010.07.011 . hal-00530054v2

\section{HAL Id: hal-00530054}

\section{https://hal-mines-paristech.archives-ouvertes.fr/hal-00530054v2}

Submitted on 15 Nov 2010

HAL is a multi-disciplinary open access archive for the deposit and dissemination of scientific research documents, whether they are published or not. The documents may come from teaching and research institutions in France or abroad, or from public or private research centers.
L'archive ouverte pluridisciplinaire HAL, est destinée au dépôt et à la diffusion de documents scientifiques de niveau recherche, publiés ou non, émanant des établissements d'enseignement et de recherche français ou étrangers, des laboratoires publics ou privés. 
MINES

$\begin{array}{lllll}\mathbf{C} & \mathbf{E} & \mathbf{R} & \mathbf{N} & \mathbf{A}\end{array}$

ParisTech

CERNA WORKING PAPER SERIES

Distributional effects of a carbon tax on car fuels in France

Benjamin Bureau

Working Paper 2010-19

Cerna, Centre d'économie industrielle

MINES ParisTech

60, boulevard Saint Michel

75272 Paris Cedex 06 - France

Tél. : 33 (1) 40519000

October 2010 


\title{
Distributional effects of a carbon tax on car fuels in France
}

\author{
Benjamin Bureau* \\ Revised version - July 2010
}

* MINES ParisTech, CERNA, 60 boulevard Saint Michel 75006 Paris, France. Email: benjamin.bureau@mines-paristech.fr. Phone: +33 (0)6 309049 31. Fax: +33 (0)1 4051 9145. 


\begin{abstract}
This paper analyses the distributional effects of alternative scenarios of carbon taxes on car fuels using disaggregated French panel data from 2003 to 2006. It incorporates household price responsiveness that differs across income groups into a consumer surplus measure of tax burden. Carbon taxation is regressive before revenue recycling. However, taking into account the benefits from congestion reduction induced by the tax mitigates regressivity. We show also that recycling additional revenues from the carbon tax either in equal amounts to each household or according to household size makes poorest households better off.
\end{abstract}

JEL classification: H23, Q48, R48.

Key words: carbon tax, distributional effects. 


\section{Introduction}

In June 2009, the French government announced its intention to introduce a carbon tax. The basic idea is to introduce an additional tax on top of existing taxes on fossil fuels which will be paid by households and firms which are not included in the EU Emission Trading Scheme. ${ }^{1}$ The aim is to achieve France's commitments to reduce greenhouse gas emissions at the lowest cost: $-14 \%$ by 2020 (compared to 2005 levels) ${ }^{2}$, and $-75 \%$ by $2050 .^{3}$

In the case of private cars, a tax on vehicle carbon emissions essentially is equivalent to a fuel tax. Higher fuel taxes may give rise to concerns about the effects of additional taxation on low-income households. For instance, it is often argued that lowincome households cannot afford to live in city centres where the supply of public transport is abundant, and therefore have no choice but to use their car to travel. Beyond equity concerns, the political acceptability of a new carbon tax clearly depends upon the proportion of the population that benefits from it.

This paper analyses the distributional effects of alternative scenarios of carbon taxes. $^{4}$ We consider two levels of taxation and explore how the welfare impacts are distributed across households that differ by income and residential location. We also simulate three scenarios of revenue recycling. Our methodology is based on a car use model that is estimated using disaggregated panel data from 2003 to 2006 . We explicitly

\footnotetext{
${ }^{1}$ The tax was initially supposed to be introduced in Jan. 2010. But it was finally postponed sine die after France's constitutional court ruled at the end of December 2009 that it would violate principles of equality because of the range of industrial emissions that would be exempt.

${ }^{2}$ France's target under the European package on climate.

${ }^{3}$ Objective set in the 2005 "Loi de programme fixant les orientations de la politique énergétique" ("Law setting orientations for the energy policy").

${ }^{4}$ We deliberately choose to focus on the distributive impact of a carbon tax on car fuels, without exploring the question of its economic efficiency. Although a major issue, a rigorous treatment of that question would require another study on its own.
} 
model and simulate individual changes in kilometres travelled that are induced by modifications in fuel taxation. Specifically, this approach allows for the possibility that different households behave differently in response to increases in the cost of driving.

Several studies have estimated the distributional effects of car fuel taxation. However, most of them utilize North-American data (e.g., Bento et al. 2005, 2009; Poterba, 1991; Røed Larsen, 2006; West, 2004). Their results do not easily transfer to Europe as the geography of urban areas, the spatial distribution of income, the relative importance of public transportation and the prevailing levels of fuel taxes are completely different. As an illustration, OECD (2006) shows that private car use, measured in passenger-kilometres per capita, is two times higher in the US than in France. A metaanalysis by Goodwin et al. (2004) also shows that the US has lower fuel consumption elasticities than Europe with respect to both price and income.

Some studies examine the distributional effects of fuel taxation using European data. Berri (2005) finds France's taxation of car fuel to be regressive. However, he does not model the changes of behaviour induced by the additional taxation. Therefore, his results are only valid for marginal tax shifts. Both Blow and Crawford (1997) and Santos and Catchesides (2005) assess the regressive effects of gasoline taxation in the United Kingdom considering the behavioural response of drivers to the increased cost of driving. Blow and Crawford find that rising fuel taxes are progressive if all households are considered but regressive if only car-owning households are considered. Santos and Catchesides find that middle-income households suffer the most from the burden when all households are considered. When only car-owning households are considered, gasoline taxation is strongly regressive. Those studies do not consider any recycling of 
the additional revenues from the tax increase. Our simulations show that accounting for revenue recycling dramatically changes the distributive impact of fuel taxation.

From a methodological point of view, two main contributions distinguish this paper. First, to the best of our knowledge, it is the first which uses panel data methods to study the distributional impacts of car use taxation. Panel data is particularly suitable for estimating the car use model as it allows controlling for the inherent endogeneity of motorisation choices. Earlier papers only had access to single or pooled cross-sections. Accordingly, they had to apply burdensome two-step approaches (e.g., West, 2004). We will examine this issue in more detail in the next section.

A second difference with all prior work is that we consider the benefits induced by the reduction of congestion due to the fuel taxation and analyse how those benefits are distributed among households. ${ }^{5}$ Congestion is generally considered to be the quantitatively most important automobile externality. For example, UNITE (2003, Table 11) shows that it accounts for $44 \%$ of the following external costs in France: global warming, air pollution, noise, congestion, and accidents. ${ }^{6}$

The paper is organized as follows. Section 2 presents the model of car use that will provide the basis for the simulations. Section 3 presents our approach for simulating scenarios of carbon taxation. Section 4 discusses the data. Section 5 presents and interprets the results. The last section concludes.

\footnotetext{
${ }^{5}$ This assertion does not include the existing literature on congestion charging which obviously considers the distributive impact of congestion reduction (see e.g., Bureau and Glachant, 2008, Eliasson and Mattsson, 2006).

${ }^{6}$ This proportion is $56 \%$ in the UK and $34 \%$ in Germany. Parry et al. (2007, table 2) provide a similar order of magnitude for the US. Congestion then represents $46 \%$ of the following costs: global warming, local pollution, oil dependency, congestion and accidents.
} 


\section{Model of car use}

This section presents the model of car use. Estimates of the model will then be used to simulate changes in fuel taxation. We consider the following standard expression for kilometres demand:

$$
\mathrm{KM}_{i t}=\alpha+\beta_{1} \cdot \mathrm{p}_{i t}+\beta_{2} \cdot\left(\mathrm{p}_{i t} \times \mathrm{y}_{i t}\right)+\gamma \cdot \mathrm{two}_{i t}+\mathrm{V}^{\prime} \cdot \delta_{1}+\mathrm{H}^{\prime} \cdot \delta_{2}+\mathrm{X}^{\prime} \cdot \delta_{3}+\mathrm{T}_{t}^{\prime} \cdot \zeta+\mathrm{a}_{i}+\varepsilon_{i t}
$$

where $i$ indexes households, $t$ indexes years, $K M$ is the annual number of kilometres the household drives, $p$ is the price per kilometre, $y$ is income per equivalised person, two indicates if the household holds two cars, $V$ is a vector of vehicle attributes, $H$ is a vector of household characteristics, $X$ is a vector of other control variables, $T$ is a vector of year dummies, $a_{i}$ is the household fixed effect, $\varepsilon_{i t}$ is the usual error term, and the remaining Greek letters denote parameters.

The linear specification of the demand function allows the demand response to $p$ to vary with the level of demand. This is a key issue in assessing the distributional effects of a rise in $p$. In contrast, a log-log specification would impose the restriction that the price elasticity is the same for all households. Furthermore, the statistical fits of levellevel, log-log, log-level and level-log models were compared. Because the R-squares of these models are not comparable, the comparison of fits involved predicting VMT from the log-log (or log-level) model given the predicted value of ln VMT. The square of the correlation between predicted and actual VMT can be compared with the R-squared obtained from the level-level (or level-log) model (Wooldridge, 2006). In all cases the level-level model was found to provide a similar or superior fit. 
Besides, to allow the price effect to vary with income, we include an interaction between income and the price per kilometre. In the estimations, $p$ and $(p \times y)$ are also interacted with specific dummy variables to allow the price effect to vary between oneand two-vehicle households.

When estimating a model of car use, a standard econometric problem deals with the endogeneity of the variables describing the number and attributes of cars held by households. This is due to the joint nature of the demands for vehicles and kilometres. The choices of vehicle and kilometres are related because characteristics that influence a household to purchase a certain number and type of vehicle may also influence that household's choice of kilometres. For example, as Mannering and Winston (1985) point out, the individual characteristics that tend to increase usage (e.g., pleasure of driving) will adversely affect the probability of selecting an old, decrepit vehicle from which little driving pleasure can be derived. In econometric terms, this correlation implies that vehicle specific attributes, which are included as explanatory variables in (1), will be correlated with the error term. In this context, using Ordinary Least Squares (OLS) may lead to biased and inconsistent estimators of parameters.

The use of panel data allows us to deal with the endogeneity problem. Indeed, the use of a fixed effect estimator permits to purge the effects of $a_{i}$, i.e., all unobserved and time invariant determinants, from (1). At last, the sole condition for the estimator to be consistent is that the idiosyncratic error $\varepsilon_{i t}$ is uncorrelated with explanatory variables. We make this assumption in the remaining of the paper. It is admittedly simplifying as the 
fixed effect estimator does not rule out the potential remaining endogeneity due to simultaneity in the choice of vehicle and in the use of the vehicle. ${ }^{7}$

Earlier papers only had access to single or pooled cross-sections. In this context, the standard procedure to deal with the endogeneity problem involves a burdensome twostep approach. First, a discrete choice model is used to estimate the probabilities of choosing different fleet sizes and compositions; these probabilities are then used in the estimation of kilometres demand to control for endogeneity (e.g., Berkowitz et al., 1990; Goldberg, 1998; Hensher et al., 1992; Mannering and Winston, 1985; Train, 1986; West, 2004). ${ }^{8}$

\section{Simulation strategy}

Having described how we model the demand for kilometres, we now describe how we simulate the different scenarios. We develop two simulation modules. The first simulates the impact of a carbon tax in France without considering the benefits induced by congestion reduction (similar to the work of earlier studies). The second module simulates the impact of a carbon tax with a consideration of the benefits of congestion mitigation. Due to data constraints, it is done for the Paris Region only. This section successively presents the two simulation modules and the scenarios considered.

\footnotetext{
${ }^{7}$ Moreover, and beyond this simultaneity problem, two of our variables, $A D D$ and $S E P$, may be endogenous even after controlling for time-invariant unobserved effects. We come back to this issue in section 4.

${ }^{8}$ This approach derives from the seminal work of Dubin and McFadden (1984) who propose models to estimate the joint demand for durables and energy use.
} 


\subsection{Measuring the impact of a carbon tax in France (without considering the benefits from congestion reduction)}

We proceed in four stages. First, we estimate econometrically the parameters of equation (1) using panel data from 2003 to 2006. Second, we simulate the changes in kilometres driven by households induced by the changes in fuel taxation. Third, we calculate individual welfare changes. Finally, we examine the distribution of welfare changes among households. The data used in the simulations refer to 2006 .

As described in the introduction, we restrict the analysis to the short-run incidence of the tax. We assume that households respond to the additional taxation solely by reducing the number of kilometres they drive. We use the change in household consumer surplus to measure the change in household welfare due to the tax. Assuming a linear demand curve for kilometres, the change in consumer surplus for household $i$ induced by an additional tax can be expressed:

$$
\Delta \mathrm{CS}_{i}=\left(\mathrm{p}_{i l}-\mathrm{p}_{i 0}\right) \cdot \mathrm{KM}_{i l}+1 / 2\left[\left(\mathrm{p}_{i l}-\mathrm{p}_{i 0}\right) \cdot\left(\mathrm{KM}_{i 0}-\mathrm{KM}_{i l}\right)\right]
$$

where $p_{i 0}$ is the initial price per kilometre for household $i, p_{i l}$ is the price per kilometre with the additional tax, $K M_{i 0}$ is the initial number of kilometres, and $K M_{i l}$ is the number of kilometres after the tax. This is the standard "rule of one-half".

It is important to note that not considering behavioural response of drivers amounts to taking into account twice the second term of (2), leading to an overestimation of the welfare impact of taxation. 


\subsection{Measuring the impact of a carbon tax in the Paris Region considering the benefits from congestion reduction}

The second module examines the impact of a carbon tax in the Paris Region considering the benefits from congestion mitigation. The Paris Region (also referred to as Ile-deFrance) is a vast area of 12,072 sq km and 10.9 million inhabitants (around 1/6 of the whole French population). The city of Paris is only a small part of that area with a surface of $105 \mathrm{sq} \mathrm{km}$ and 2.1 million inhabitants.

Apart from congestion considerations, the simulation strategy is essentially the same as the one presented in section 3.1. The sole difference is that, when estimating the car use model, all price variables are now interacted with specific dummy variables to allow the price effect to vary between the Paris Region and the rest of the country. Results of the regression are given in the Appendix.

The benefits from congestion reduction are calculated for each household as the monetary value of time savings on annual kilometres driven by the household ${ }^{9}$ after the introduction of the carbon tax. ${ }^{10}$ These calculations require three types of information: first, an evaluation of the impact of the carbon tax on traffic; second, an estimation of the impact of traffic reduction on individual travel times; and third, values of travel time (VOT) to monetise the time savings.

The impact of carbon pricing on traffic is obtained using basically the same approach as in the first simulation module. First we estimate econometrically the

\footnotetext{
${ }^{9}$ Due to data constraints, kilometres driven during weekends, holidays and/or outside the Paris Region are not considered.

${ }^{10}$ Benefits from congestion reduction are calculated using 2001-2002 data while the other impacts are calculated for our most recent data, i.e., 2006. We believe this difference in not problematic as one can reasonably assume that traffic conditions in the Region have not changed much within 4-5 years. Note also that simulations for the non-congestion impacts have been conducted for the years 2003, 2004 and 2005 producing very similar results to 2006 .
} 
parameters of equation (1) using panel data from 2003 to $2006 .{ }^{11}$ Next, we simulate the changes in kilometres driven by households induced by the changes in fuel taxation. Adding up all changes, we obtain the total traffic reduction for the Paris Region.

As the next step, we must translate the traffic reduction into time savings. This is done using disaggregated data from the Paris Region Global Transport Survey carried out in 2001-2002. Time savings are calculated using a speed-flow function estimated econometrically on a sample describing traffic levels and speeds for 21 time slots. For each slot, we calculate both the total traffic by car and the average speed of car trips in the region. The regression of the logarithm of traffic on the average speed gives the following relationship (with standard errors in parentheses):

$$
\begin{aligned}
& \text { SPEED }_{C A R}=-35.2 \times \ln (\text { TRAFFIC })+621.3 \\
& n=21, R^{2}=.48
\end{aligned}
$$

where SPEED $_{\text {CAR }}$ is the average speed of car trips in meters per minute in a given slot and TRAFFIC is the total number of trips per slot ${ }^{12}$. Additionally we assume that buses also benefit from traffic reduction, as one may expect. Regressing the speed of buses on car traffic levels for 18 time slots ${ }^{13}$ gives the following relationship:

$$
\text { SPEED } D_{B U S}=-9.4 \times \ln (\text { TRAFFIC })+193.9
$$

$$
n=18, R^{2}=.19
$$

\footnotetext{
${ }^{11}$ The sole difference with the first module is that, when estimating equation (1), all price variables are interacted with specific dummy variables to allow the price effect to vary between the Paris Region and the rest of the country. The idea is to obtain a percentage of traffic reduction that is specific to the Paris Region.

${ }^{12}$ The level of traffic taken into account is the total traffic observed in the Global Transport Survey, i.e., the traffic due to individual trips. It excludes deliveries and freight.

${ }_{13}$ Contrary to the regression for cars, time slots corresponding to the night are not taken into account because the level of service is too limited.
} 
where $\mathrm{SPEED}_{\mathrm{BUS}}$ is the average speed of bus trips in meters per minute in a given slot and TRAFFIC is the total number of trips per slot. ${ }^{14}$

We assume that each household reduces its number of kilometres in response to the introduction of the tax, and consider time savings on the remaining kilometres only. ${ }^{15}$ We assume also that the traffic reduction (in \%) induced by carbon pricing is the same whatever the time of the day or the location in the Paris Region. This is admittedly a restrictive assumption as travellers may respond to the carbon tax by reducing non-work trips first. Then, implementation of a carbon tax may lead to smaller traffic reductions in business areas and/or during the peak period. This assumption must be remembered when interpreting the results.

Individual time savings are finally monetised using values of travel time from two previous studies by Bureau and Glachant (2008) and De Palma and Fontan (2001). Both papers provide values of travel time for commuters that vary with income and that are specific to the Paris Region. Table 1 presents these values per quintile of income. Income group 1 includes the $20 \%$ of individuals who have the lowest income; quintiles 1 and 2 include the $40 \%$ of individuals who have the lowest income, and so on. Table 1 reveals that the two papers propose substantially different set of values. De Palma and Fontan propose higher values on average: around $15 € / \mathrm{h}$ versus $8 € / \mathrm{h}$ for Bureau and Glachant. On the other hand, the latter give relatively higher VOT to high-income travellers as compared to low-income ones. As there are no obvious reasons to prefer one to the other,

\footnotetext{
${ }^{14}$ Logarithm functional forms give the highest goodness of fit for the two speed-flow functions.

${ }^{15}$ In order to calculate individual responses to the tax, we need to make assumptions about the price sensitivity of each household present in the Global Transport Survey. We assume that the price sensitivity depends on income and use the elasticities calculated for different income groups with the "Parc Auto" data.
} 
we consider the two sets of values for purpose of sensitivity analysis ${ }^{16}$. In the remainder of the paper, we refer to Bureau and Glachant's results as "low VOT" and to De Palma and Fontan's as "high VOT".

Whatever the values considered (low or high) Table 1 shows a clear and positive relationship between income and value of time. This is particularly noticeable in the "low VOT" case: the VOT of the wealthiest individuals is almost twice the VOT of the poorest. Thus not considering values of time that vary with income would lead to substantial biases in the assessment of the distributional effects of congestion reduction.

The two papers provide values of travel time for commuters only. However, empirical findings converge to suggest that the value of travel time savings is lower for non-work purposes than for commuting (see e.g., Small and Verhoef, 2007). The difference varies according to studies and locations. In this paper, we consider that values of travel time for "other purposes" are $45 \%$ below that for commuting. This is the ratio recommended by Commissariat Général du Plan (2001, p. 42) for the Paris Region.

Table 1: Values of travel time for commuters for different groups of travellers (2002 $€$ per hour)

\begin{tabular}{|c|c|c|c|}
\hline \multirow[t]{2}{*}{ Income group } & \multicolumn{2}{|c|}{ Low value $^{a}$} & \multirow[t]{2}{*}{ High value $^{b}$} \\
\hline & $\begin{array}{c}\text { Private car } \\
\text { users }\end{array}$ & $\begin{array}{c}\text { Public transport } \\
\text { users }\end{array}$ & \\
\hline 1 & 5.0 & 6.0 & 13.3 \\
\hline 2 & 6.7 & 7.2 & 14.2 \\
\hline 3 & 7.9 & 8.0 & 14.9 \\
\hline 4 & 10.0 & 9.9 & 15.8 \\
\hline 5 & 11.4 & 11.4 & 16.1 \\
\hline All & 7.9 & 8.2 & 14.9 \\
\hline
\end{tabular}

${ }^{\text {a }}$ Bureau and Glachant (2008, Table 3)

b Author's calculation using initial figures from De Palma and Fontan (2001, Table 3) - which give values of travel time for solely three groups of household income.

\footnotetext{
${ }^{16}$ Potential reasons for differences between the two studies are discussed in the Appendix.
} 


\subsection{Scenarios}

Table 2 describes the six scenarios. As a benchmark, we consider an additional carbon tax of 7.1 euro-cents per litre of gasoline and 8.1 cents per litre of diesel. Those values refer to a cost of $\mathrm{CO}_{2}$ of $€ 31$ per tonne (in 2006€). This is the official figure to be used in France (by 2010) when evaluating public investment choices or, more generally, when making environmental evaluation of public policies (CAS, 2008). This was set in order to achieve the European political objectives of March 2007, and lies at the high end of the spectrum of international evaluations of external costs of carbon (see e.g., Delft, 2008).

Next, we consider several variations of this reference scenario. First, a higher taxation of carbon: 12.4 cents per litre of gasoline and 14.0 cents per litre of diesel. It corresponds to $€ 54$ per tonne of $\mathrm{CO}_{2}$ (in 2006€), which is the official figure to be used in France by 2020. The idea is to investigate if the level of taxation impacts the distribution of burdens among households. We also consider three alternative ways of recycling the additional revenues from the tax increase:

- "flat" recycling: revenues are returned in equal amounts to every household;

- "size-based" recycling: revenues are allocated according to the number of equivalised persons in the household. In the whole paper, the "OECD modified scale" is used to define equivalised persons (or "consumption units"), i.e., the first adult gets the weight 1 , other members aged 14 or more get 0.5 , children aged less than 14 get 0.3 ;

- "income-based" recycling: revenues are allocated to households according to each household's share of aggregate income. 
Our methodological framework can handle both alternatives because they involve lump sum transfers to all households. One may reasonably assume that such transfers do not modify significantly households' demand for kilometres ${ }^{17}$. To obtain the overall individual welfare changes, we simply add lump sum transfers to individual surplus variations induced by the carbon tax to obtain the overall individual welfare changes. We consider that recycling is accomplished on an annual basis and assume that it does not involve additional costs to the government.

Table 2: Description of the six scenarios

\begin{tabular}{|l|c|c|c|}
\hline Scenario name & Carbon tax & $\begin{array}{c}\text { Redistribution } \\
\text { of carbon tax } \\
\text { revenues }\end{array}$ & $\begin{array}{c}\text { Redistributed } \\
\text { amount } \\
\text { (per annum) }\end{array}$ \\
\hline Reference & $\begin{array}{c}\text { Gasoline: } € 0.071 / \mathrm{L} . \\
\text { Diesel: } € 0.081 / \mathrm{L} .\end{array}$ & No & - \\
\hline $\begin{array}{l}\text { Reference - Flat } \\
\text { recycling }\end{array}$ & $\begin{array}{c}\text { Gasoline: } € 0.071 / \mathrm{L} . \\
\text { Diesel: } € 0.081 / \mathrm{L} .\end{array}$ & Yes & $€ 64$ \\
\hline $\begin{array}{l}\text { Reference }- \text { Size- } \\
\text { based recycling }\end{array}$ & $\begin{array}{c}\text { Gasoline: } € 0.071 / \mathrm{L} . \\
\text { Diesel: } € 0.081 / \mathrm{L} .\end{array}$ & Yes & $\begin{array}{c}€ 41 \text { per } \\
\text { equivalised person }\end{array}$ \\
\hline $\begin{array}{l}\text { Reference }- \\
\text { Income-based } \\
\text { recycling }\end{array}$ & $\begin{array}{c}\text { Gasoline: } € 0.071 / \mathrm{L} . \\
\text { Diesel: } € 0.081 / \mathrm{L} .\end{array}$ & Yes & $€ 64$ on avg. \\
\hline $\begin{array}{l}\text { High tax } \\
\text { Gasoline: } € 0.124 / \mathrm{L} . \\
\text { Diesel: } € 0.140 / \mathrm{L} .\end{array}$ & No & - \\
\hline $\begin{array}{l}\text { High tax }- \text { Flat } \\
\text { recycling }\end{array}$ & $\begin{array}{c}\text { Gasoline: } € 0.124 / \mathrm{L} . \\
\text { Diesel: } € 0.140 / \mathrm{L} .\end{array}$ & Yes & $€ 110$ \\
\hline $\begin{array}{l}\text { High tax }- \text { Size- } \\
\text { based recycling }\end{array}$ & $\begin{array}{c}\text { Gasoline: } € 0.124 / \mathrm{L} . \\
\text { Diesel: } € 0.140 / \mathrm{L} .\end{array}$ & Yes & $\begin{array}{c}€ 1 \text { per } \\
\text { equivalised person }\end{array}$ \\
\hline $\begin{array}{l}\text { High tax }- \\
\text { Income-based } \\
\text { recycling }\end{array}$ & $\begin{array}{c}\text { Gasoline: } € 0.124 / \mathrm{L} . \\
\text { Diesel: } € 0.140 / \mathrm{L} .\end{array}$ & Yes & $€ 110$ on avg. \\
\hline
\end{tabular}

\footnotetext{
${ }^{17}$ As we will see in section 5, our estimations show that the impact of income on demand for kilometres is small and hardly significant.
} 


\section{Data and summary statistics}

Our data come from two sources. The first is the "Panel Parc Auto TNS-Sofres" which we use to estimate the model of car use and to analyse the distribution of costs induced by the carbon tax. The second is the Paris Region Global Transport Survey which we use to examine the distribution of benefits induced by congestion reduction. This section presents the two successively.

\subsection{Panel Parc Auto TNS-Sofres}

\subsubsection{General description}

The "Panel Parc Auto TNS-Sofres" (hereafter "Parc Auto") is the main component of the data. This survey has been carried out annually in France for twenty-five years. We use the last four waves of the panel: 2003 to 2006. "Parc Auto" describes the number of vehicles held by households, the technical attributes of those vehicles (e.g., age, type, fuel) and their usage. It also includes the socio-economic and geographical characteristics of the households surveyed. About 6,500 households are surveyed each year. On average, two-thirds are re-interviewed the following year while the others drop out of the panel and are replaced by new ones.

Our estimations are limited to motorized households who own one or two cars. As stated above, we are only concerned with the response of households in terms of usage, not in terms of car ownership. Therefore we do not consider non-motorized households in our estimations ${ }^{18}$. Furthermore, not enough three-or-more-vehicle households remained in our sample after cleaning to produce sound estimates. Those households were then

\footnotetext{
${ }^{18}$ However, non-motorized households are taken into account when measuring the welfare impacts of additional taxation, considering their welfare change to be 0 .
} 
systematically dropped out. Note however that less than $7 \%$ of French households in 2006 owned three-or-more vehicles. Because we use a fixed effect estimator, households who are present only once in the panel are not included in our sample. Careful examination of data also revealed obvious measurement errors in the variable "number of kilometres driven" for households who replaced one of their cars within the year of survey. We did not include those observations in the sample. Finally, observations with missing values for key explanatory variables were also excluded. Overall this leaves us with an unbalanced panel of 2,956 households with 7,915 observations over the period $2003-2006^{19}$.

To construct a price per kilometre variable fuel prices and the fuel efficiency of each vehicle are needed. For fuel prices, we use annual average prices provided by the French Ministry in charge of energy. "Parc Auto" contains data on fuel efficiency. Households are asked to give an estimation of the fuel efficiency of each of their vehicles. We do not consider this information directly; rather, we use it to estimate average fuel efficiencies per type of vehicle ${ }^{20}$. The idea is that some households may over-estimate or under-estimate the fuel efficiency of their fleet but we assume that, on average, households' estimations are correct. For two-vehicle households, the price per kilometre considered in the estimation is the average of the price per kilometre of the two vehicles.

\footnotetext{
${ }^{19} 49 \%$ of households are surveyed two years, $34 \%$ are surveyed three years and $17 \%$ are surveyed four years.

${ }^{20}$ On total, more than 180 types of vehicles are considered according to fuel type, engine size, market segment, and age. Fuel efficiencies vary also according to the year of survey. Estimation is carried out by OLS. Results are available upon request.
} 


\subsubsection{Variable definitions and summary statistics}

Table 3 presents the variables used for the estimation of the car use model and the main descriptive statistics of the sample. For example, it indicates that households drive 14,601 kilometres a year on average, $26 \%$ hold two vehicles and $35 \%$ live in peri-urban or rural areas.

Most of the variables used for the estimation are standard in car use modelling. Some deserve specific attention: "Parc Auto" classifies vehicles into nine market segments. In order to have enough observations for each variable, some were grouped together, creating four market segments: downmarket (e.g., Renault Clio, VW Polo), mid-range (e.g., Peugeot 307, VW Golf), upmarket or SUVs (e.g., Mercedes-Benz EClass, BMW 7 Series) and utility vehicles. Note also that for each vehicle the household owns at the end of the year, "Parc Auto" describes its use over the last twelve months. Because the fleet size may vary during the year, two control variables are included in the estimation: $A D D$, which indicates that the household bought an additional car during the year and SEP, which indicates that the household parted with one car. We expect the former to decrease the number of kilometres the household drives - because it had not had the additional vehicle for twelve months. Conversely, we expect SEP to increase the number of kilometres the household drives with the remaining vehicle - reflecting some kind of inertia in household's activity pattern. Note that the two variables may be endogenous even after controlling for time-invariant unobserved effects. As non-regular choices made by households, they may indeed be correlated with $\varepsilon_{\mathrm{it}}$. No valid instruments being available, we ran the estimation without including households with $A D D$ or SEP 
equal to one. This robustness check did not change significantly the estimates of other key variables.

Finally, we choose not to include a variable describing fuel type (i.e., gasoline or diesel) in the estimation. This is not necessary because we believe that the sole influence of fuel type on kilometres is via fuel efficiency (diesel vehicles are more fuel efficient on average), and this is reflected already in the price per kilometre. Another characteristic of diesel cars is that they are usually considered to have a longer lifetime. A priori, such information is not correlated with any of our explanatory variables, therefore there is no harm to leave the fuel type information in the error term. 
Table 3: Descriptive statistics

\begin{tabular}{|c|c|c|c|}
\hline Variable & Definition & Mean & Std. Dev. \\
\hline KM & Total kilometres driven & 14601 & 9127 \\
\hline $\mathrm{P}$ & Price per kilometre & 0.0791 & 0.0157 \\
\hline p*INCOME & Price per kilometre*income per capita & 1523 & 930 \\
\hline ONE & $=1$ if household holds one vehicle & 0.74 & 0.44 \\
\hline TWO & $=1$ if household holds two vehicles & 0.26 & 0.44 \\
\hline DOWNMARKET & $=1$ if a 1-vehicle household holds a downmarket vehicle & 0.31 & 0.46 \\
\hline MIDRANGE & $=1$ if a 1 -vehicle household holds a mid-range vehicle & 0.39 & 0.49 \\
\hline UTILITY & $=1$ if a 1-vehicle household holds a utility vehicle & 0.01 & 0.08 \\
\hline DOWN_DOWN & $=1$ if a 2 -vehicle household holds two downmarket vehicles & 0.03 & 0.17 \\
\hline DOWN_MID & $=1$ if 2 -vehicle household holds a downmarket and a mid-range vehicle & 0.13 & 0.34 \\
\hline DOWN_UP & $=1$ if a 2 -vehicle household holds a downmarket and a upmarket vehicle & 0.03 & 0.16 \\
\hline MID_MID & $=1$ if a 2 -vehicle household holds two mid-range vehicles & 0.04 & 0.19 \\
\hline MID_UP & $=1$ if a 2 -vehicle household holds a mid-range and a upmarket vehicle & 0.01 & 0.10 \\
\hline UTILITY_2V & $=1$ if a 2 -vehicle household holds a least one utility vehicle & 0.02 & 0.15 \\
\hline NEW & $=1$ if a 1 -vehicle household holds a new car (less than 2 years) & 0.07 & 0.25 \\
\hline OLD_NEW & $=1$ if a 2 -vehicle household holds one new car & 0.04 & 0.19 \\
\hline NEW_NEW & $=1$ if a 2 -vehicle household holds two new cars & 0.00 & 0.05 \\
\hline NB_ADULTS & Number of adults (18 years old or more) & 1.8 & 0.7 \\
\hline $\mathrm{Q}_{\mathrm{j}}$ & $=1$ if household belongs to the $j$-th quintile of income per capita $(j=2, \ldots, 5)$ & - & - \\
\hline SUBURB $^{\mathrm{a}}$ & $=1$ if household lives in a suburban area & 0.34 & 0.47 \\
\hline PERIURBAN $^{\mathrm{a}}$ & $=1$ if household lives in a periurban area & 0.33 & 0.47 \\
\hline RURAL $^{\mathrm{a}}$ & $=1$ if household lives in a rural area & 0.02 & 0.16 \\
\hline ADD & $=1$ if fleet size increased during the year & 0.02 & 0.13 \\
\hline SEP & $=1$ if fleet size decreased during the year & 0.01 & 0.10 \\
\hline YEAR-j & Year dummies $(j=2004,2005,2006)$ & - & - \\
\hline FEMALE & $=1$ if head of household is female & 0.19 & 0.39 \\
\hline AGE & Age of household head & 58 & 15 \\
\hline NB_DL & Number of household members with a driving licence & 1.6 & 0.5 \\
\hline NORTH & $=1$ if household lives in the North & 0.07 & 0.26 \\
\hline EAST & $=1$ if household lives in the East & 0.10 & 0.30 \\
\hline WEST & $=1$ if household lives in the West & 0.14 & 0.34 \\
\hline SOUTH_WEST & $=1$ if household lives in the South West & 0.10 & 0.30 \\
\hline SOUTH_EAST & $=1$ if the household lives in the South East & 0.24 & 0.43 \\
\hline
\end{tabular}

${ }^{\mathrm{a}}$ Four types of location are considered: city centres, suburbs, peri-urban zones and rural areas. This coding was developed by the French National Institute for Transport and Safety Research (INRETS).

\subsubsection{Test of sample selection bias}

When filling the survey questionnaire of "Parc Auto", households are asked to give details on the attributes and usage of all their cars. Clearly, multi-motorized households would find this process more tedious. As a consequence, multi-motorized households are less likely to stay in the panel than mono-motorized ones. In other words, the decision to rotate households out of the panel is not fully random, so that a sample selection problem 
may result. Wooldridge (2002, p. 581) provides a simple test for sample selection bias in the context of fixed effect estimation with unbalanced panel. The test relies on the fact that sample selection in a fixed effects context is only a problem when selection is related to the idiosyncratic errors, $\varepsilon_{\mathrm{it}}$. Thus, Wooldridge suggests adding the lagged selection indicator, $\mathrm{s}_{\mathrm{i}, \mathrm{t}-1}$, to the equation $\left(\mathrm{s}_{\mathrm{i}, \mathrm{t}-1}\right.$ equals 1 if household $i$ is present in the panel at time $t-1,0$ otherwise), estimate the model by fixed effects, and do a $t$ test for the significance of $\mathrm{s}_{\mathrm{i}, \mathrm{t}-1}$. Under the null hypothesis, $\varepsilon_{\mathrm{it}}$ is uncorrelated with $\mathrm{s}_{i r}$ for all $r$, and so selection in the previous time period should not be significant at time $t .{ }^{21}$ In our case, a robust $t$ test strongly supports the hypothesis of no sample selection bias.

\subsection{Global Transport Survey}

The second set of data we use is the 2001-2002 Paris Region Global Transport Survey (Enquête Globale Transport Ile-de-France 2001-2002). This survey has been carried out regularly for 25 years. It allows us to follow and to analyse trip patterns in the Paris Region.-The sample surveyed is representative of the Region population with respect to social and geographical characteristics. 10,500 households were surveyed between October 2001 and April 2002. Each member of the household older than 6 is interviewed about all the trips she/he made the day before the survey. For each trip, a broad variety of data is available, for example: time of departure and arrival, trip purpose, origin, destination, and mode(s) used. General household characteristics are also described (e.g., size, location, income) as well as characteristics of each member (e.g., age, sex, profession).

\footnotetext{
${ }^{21}$ This approach was first suggested by Nijman and Verbeek (1992) in the context of random effects estimation.
} 


\section{Estimation and results}

\subsection{Estimation of the model of car use}

The results from the estimation of the car use model are reported in Table 4. As mentioned earlier, we use a fixed effect estimator to control for the potential endogeneity of the explanatory variables describing fleet size and composition. For comparison purpose, Table 4 also reports estimation results with pooled OLS and random effects (RE). We know that those methods will generally lead to inconsistent estimators if the (unobserved to the econometrician) household-specific effects $a_{i}$ are correlated with any of the explanatory variables. As expected, pooled OLS and RE produce substantially different results than FE indicating correlation between $a_{i}$ and the explanatory variables. Formally, a standard Hausman test strongly rejects the assumption of similar RE and FE estimates. In addition, we ran an $F$ test to test the null hypothesis that the constant terms are equal across households. The hypothesis is strongly rejected, implying that pooled OLS would be inappropriate. For the rest of the paper we then focus on FE estimates.

The price coefficients are significant ${ }^{22}$ and of expected sign. Households drive less as price per kilometre increases but richer households are less price sensitive. As expected, households with two cars drive more, as do those owning a recent car - though this last result is only significant for one-vehicle households. On the contrary, market segment dummies have very little explanatory power. ${ }^{23,24}$

\footnotetext{
${ }^{22}$ Because of the interaction effects, one may take care not to look separately at the price coefficients. Then, even if the coefficient of $p * I N C O M E^{*} T W O$ is not significant at the $10 \%$ level (it is though at the $13 \%$ level), an F-test strongly rejects the joint hypothesis that $p * T W O$ and $p * I N C O M E * T W O$ equal zero.

${ }^{23}$ Tests on coefficients exhibit only two exceptions: the $3 \%$ of households that own a downmarket and an upmarket vehicle drive more than most of the other two-vehicle households. Moreover, one-vehicle households that own a mid-range vehicle drive more than the $0.7 \%$ of households owning a utility vehicle.

${ }^{24}$ A similar result is found by Goldberg (1998) for the US.
} 
Unsurprisingly, households with more adults drive more, as do those living in peri-urban or rural areas. Interestingly, the effect of income per capita is negative though only just significant ${ }^{25}$. This is so because our model produces estimates holding the number of cars constant. In their extensive review of demand elasticity studies, Goodwin et al. (2004) note that when income increases, the number of vehicles increases relatively more than the volume of traffic. Such a result implies that use per vehicle should decline as income increases.

As expected, households that have had one of their vehicles for fewer than 12 months drive less. Conversely, two-car households that part with one of their vehicles during the year drive more with the remaining one, reflecting some kind of inertia in their activity pattern.

\footnotetext{
${ }^{25}$ The negative sign holds whatever the specification of income: continuous or dummy variables, total or per equivalised person income, but not the significativity.
} 
Table 4: Kilometre demand results

\begin{tabular}{|c|c|c|c|c|c|c|}
\hline & \multicolumn{2}{|c|}{ OLS } & \multicolumn{2}{|c|}{$\mathrm{RE}$} & \multicolumn{2}{|l|}{$\mathrm{FE}$} \\
\hline p*ONE & $-128,233 * * *$ & $(8444)$ & $-109,804 * * *$ & (7559) & $-40,989 * * *$ & (15501) \\
\hline p*TWO & $-246,077 * * *$ & (23795) & $-187,422 * * *$ & $(18083)$ & $-78,174 * * *$ & (26906) \\
\hline $\mathrm{p}^{*} \mathrm{INCOME} \mathrm{N}^{*} \mathrm{ONE}$ & 0.258 & $(0.24)$ & $0.463 * * *$ & $(0.16)$ & $0.466^{* * *}$ & $(0.17)$ \\
\hline $\mathrm{p}^{*} \mathrm{INCOME}{ }^{*} \mathrm{TWO}$ & 0.313 & $(0.37)$ & 0.345 & $(0.26)$ & 0.531 & $(0.35)$ \\
\hline TWO & $15,423.9 * * *$ & (2729.3) & $12,498.1 * * *$ & $(2518.0)$ & $11,550.6 * * *$ & (3222.8) \\
\hline DOWNMARKET & $-3,876.6 * * *$ & $(558.1)$ & $-3,020.4 * * *$ & $(484.6)$ & -504.4 & (1098.6) \\
\hline MIDRANGE & $-1,252.0 * *$ & $(530.4)$ & $-817.6^{*}$ & $(458.1)$ & 247.3 & $(936.2)$ \\
\hline UTILITY & -863.9 & $(951.7)$ & $-1,792.0 * *$ & $(901.5)$ & $-1,628.4$ & (1258.4) \\
\hline DOWN_DOWN & $-2,544.4$ & (1827.4) & $-1,088.3$ & $(2146.9)$ & -636.1 & (2934.5) \\
\hline DOWN_MID & -603.5 & (1704.7) & 642.7 & $(2033.2)$ & 104.3 & $(2748.2)$ \\
\hline DOWN_UP & 740.7 & (1653.6) & $2,921.2$ & $(2039.5)$ & $2,933.7$ & $(2805.0)$ \\
\hline MID_MID & 684.5 & (1814.4) & $1,128.1$ & $(2095.7)$ & -166.0 & $(2828.8)$ \\
\hline MID_UP & $3,181.7 *$ & (1825.9) & $3,349.0$ & $(2143.0)$ & 511.5 & (3122.6) \\
\hline UTILITY_2V & -419.9 & $(1609.2)$ & $1,309.9$ & (2042.7) & $2,123.0$ & (2799.4) \\
\hline NEW & $1,679.8 * * *$ & $(276.7)$ & $612.5 * * *$ & $(178.2)$ & $338.0 *$ & $(182.0)$ \\
\hline OLD_NEW & $946.7 *$ & $(557.4)$ & 313.0 & $(377.3)$ & 157.8 & (397.4) \\
\hline NEW_NEW & $4,250.7 *$ & (2490.1) & $3,659.6^{*}$ & (1989.8) & $3,029.6$ & $(2176.1)$ \\
\hline NB_ADULTS & $1,093.0 * * *$ & $(240.3)$ & $925.8 * * *$ & (231.6) & $1,004.7 * *$ & (418.9) \\
\hline Q2 & $1,060.8 * * *$ & (329.8) & 81.9 & $(231.0)$ & $-427.3^{*}$ & (256.5) \\
\hline Q3 & $1,414.9 * * *$ & $(361.3)$ & 323.5 & $(251.9)$ & -475.0 & (294.3) \\
\hline Q4 & $2,275.0 * * *$ & $(420.4)$ & $707.7 * *$ & $(293.8)$ & -470.5 & $(346.4)$ \\
\hline Q5 & $2,701.4 * * *$ & $(586.1)$ & $711.5^{*}$ & $(385.4)$ & $-764.8^{*}$ & $(443.0)$ \\
\hline SUBURB & -20.8 & (262.4) & -45.9 & (269.4) & -199.3 & (953.7) \\
\hline PERIURBAN & $2,151.3 * * *$ & $(274.1)$ & $2,088.9 * * *$ & $(281.0)$ & $2,609.8^{* *}$ & (1058.9) \\
\hline RURAL & 1234.4 & (921.5) & $1,483.7 * *$ & $(749.7)$ & $6,096.8 * * *$ & (1966.4) \\
\hline ADD & $-2,428.9 * * *$ & (736.5) & $-2,661.9 * * *$ & $(553.0)$ & $-2,508.9 * * *$ & $(661.9)$ \\
\hline SEP & 279.3 & (753.6) & $1,101.4^{*}$ & $(589.6)$ & $1,670.7 * *$ & $(746.1)$ \\
\hline YEAR04 & $532.4 * * *$ & $(150.2)$ & $345.9 * * *$ & $(120.0)$ & -6.1 & $(123.1)$ \\
\hline YEAR05 & $1,226.0 * * *$ & $(178.3)$ & $867.7 * * *$ & (136.4) & -168.8 & (192.2) \\
\hline YEAR06 & $1,322.5 * * *$ & (194.6) & $892.5^{* * * *}$ & $(150.7)$ & $-440.9 * *$ & (220.4) \\
\hline FEMALE & $-1,220.0 * * *$ & $(332.8)$ & $-1,535.7 * * *$ & $(324.0)$ & & \\
\hline AGE & $-141.4 * * *$ & (7.3) & $-145.5 * * *$ & (7.7) & & \\
\hline NB_DL & $709.0 * *$ & (277.8) & $491.4 *$ & $(272.9)$ & & \\
\hline NORTH & 290.7 & $(459.1)$ & 177.6 & $(476.4)$ & & \\
\hline EAST & 603.3 & $(397.2)$ & 454.0 & $(398.1)$ & & \\
\hline WEST & $1,045.6 * * *$ & $(353.1)$ & $635.2 *$ & (358.6) & & \\
\hline SOUTH_WEST & 225.0 & $(406.3)$ & 32.6 & $(426.6)$ & & \\
\hline SOUTH_EAST & 176.3 & $(283.3)$ & 179.9 & $(297.8)$ & & \\
\hline CONSTANT & $26,179.8$ *** & (1109.2) & $26,414.7 * * *$ & $(1012.4)$ & $12,616.5 * * *$ & (1873.69) \\
\hline Observations & 79 & & 791 & & 7915 & \\
\hline $\mathrm{R} 2$ & 0.5 & & 0.4 & & 0.36 & \\
\hline
\end{tabular}

Notes: Dependent variable is KM. Robust standard errors in parentheses. * indicate significance at the $10 \%$ level. ** Idem, 5\%.*** Idem, $1 \%$.

\subsection{Elasticities}

Results of the estimations are used to calculate the elasticity of demand for kilometres with respect to price per kilometre. Because vehicle choices are held constant, this 
elasticity corresponds to a short run response. Using FE results and sample means of kilometres, price per kilometre and income, yields an elasticity of -0.22 , which is fairly in line with the literature (see e.g., Graham and Glaister, 2002, Goodwin et al., 2004).

Table 5 lists elasticities of demand by income group. Demand elasticities clearly vary across quintiles. In absolute value, elasticity declines with income, which is a pretty intuitive result. A similar outcome is found in Blow and Crawford (1997) and Santos and Catchesides (2005) for the UK, and in West (2004) for the U.S. ${ }^{26}$ Table 5 also presents elasticities of demand by income group and geographical location. Whatever the income group, peri-urban or rural households respond less to price change than urban households. This is mainly due to the reduced availability of alternative transport modes in peri-urban and rural areas. This aligns with the results of Blow and Crawford (1997) and Santos and Catchesides (2005) for the UK.

Table 5: Kilometres demand elasticities by quintile ${ }^{\mathrm{a}}$

\begin{tabular}{cccc}
\hline Quintiles & $\begin{array}{c}\text { All motorized } \\
\text { households }\end{array}$ & $\begin{array}{c}\text { Urban motorized } \\
\text { households }\end{array}$ & $\begin{array}{c}\text { Peri-urban or } \\
\text { rural motorized } \\
\text { households }\end{array}$ \\
\hline 1 & -0.28 & -0.30 & -0.25 \\
2 & -0.25 & -0.29 & -0.22 \\
3 & -0.23 & -0.25 & -0.20 \\
4 & -0.21 & -0.22 & -0.19 \\
5 & -0.18 & -0.19 & -0.17 \\
\hline a Demand elasticities are calculated at the mean price per kilometre, kilometres, and income, by quintile, \\
\multicolumn{4}{c}{ using FE results. }
\end{tabular}

\footnotetext{
${ }^{26}$ Though, in West (2004), the richest households (decile 9 plus decile 10) are slightly more elastic than the preceding income group (decile 7 plus decile 8 ).
} 


\subsection{Results of the simulations}

5.3.1. Impact of a carbon tax in France (without considering the benefits from congestion reduction)

With the estimates of the car use model and the data on households' mobility and price per kilometre, we can now simulate the impact of various scenarios of carbon taxes on households' welfare. Table 6 presents the results for the reference scenario: an additional carbon tax of 7.1 cents per litre of gasoline and 8.1 cents per litre of diesel without recycling of the tax revenues. Losses clearly increase with income: from $€ 71$ per annum for lower income motorized households to $€ 88$ for the wealthiest motorized households $(+23 \%)$. This is not surprising because richer households own more cars, drive more and are less price-sensitive. The result is even stronger if one considers all households, rather than vehicle-owning households alone. The richest households (quintile 5) lose $43 \%$ more than the poorest (quintile 1). This is so because the percentage of non-motorized households decreases with income: $25 \%$ in quintiles 1 or 2 , just $12 \%$ in quintile 5 .

As expected, households living in peri-urban or rural areas lose more. This result holds even after controlling for income. The difference is striking for the poorest households. Households of quintile 1 that live in peri-urban or rural areas lose $90 \%$ more than other households of quintile 1 ( $€ 72$ versus $€ 38$ ).

When considering surplus variations in percentage of income, Table 6 reveals that low-incomes lose more than richer households, meaning that the tax is regressive.

Table 7 presents the results of simulations for a heavier taxation of carbon: 12.4 cents per litre of gasoline and 14.0 cents per litre of diesel. Such heavier taxation mechanically increases the magnitude of losses but not their distribution across income groups or geographical locations. 
We now consider scenarios where the additional revenues from the carbon tax are returned in equal amounts to every household ("flat" recycling); according to the number of equivalised persons in the household ("size-based" recycling); or according to each household's share of aggregate income ("income-based" recycling). Table 6 and Table 7 exhibit dramatically different results than in scenarios without recycling.

First consider the reference scenario. When the whole population is considered, the poorest households (quintiles 1 and 2) are net gainers under "flat" and "size-based" recycling. This is because the proportion of non-motorized households - those that benefit from the revenue distribution without incurring any cost - decreases with income. Then the two recycling scenarios are globally progressive. Interestingly, the progressivity increases with the level of carbon taxation. Table 7 which presents the results for the "High taxation" scenario, exhibits greater variation in welfare impacts.

The "size-based" recycling scenario is the most progressive option: low-incomes gain more and high-incomes lose more. The reason is that households of quintile 1 are bigger on average (1.77 equivalised persons versus 1.58 for the whole population). If we focus on motorized households, the carbon tax is still progressive in the "size-based" recycling scenario but not in the "flat" recycling scenario.

In contrast, "income-based" recycling is strongly regressive: rich households (quintiles 4 and 5) stand to gain while other households are net losers.

Table 6 shows that on average households living in urban areas are net gainers under whichever recycling method while those living in peri-urban or rural zones are net losers. In other words, carbon taxation with recycling implies transferring welfare from peri-urban or rural areas to urban zones. This phenomenon increases with the level of 
taxation (Table 7). However, within the whole population of peri-urban and rural households, carbon taxation with recycling remains progressive under "flat" and "sizebased" recycling. 
Table 6: Simulation results of the reference scenario ${ }^{\mathrm{a}}$

\begin{tabular}{|c|c|c|c|c|c|c|c|c|c|c|c|c|}
\hline \multirow[t]{3}{*}{ Quintile } & \multicolumn{2}{|c|}{$\begin{array}{l}\text { Change in consumer surplus } \\
(€ \text { per annum })\end{array}$} & \multicolumn{2}{|c|}{$\begin{array}{l}\text { Change in consumer } \\
\text { surplus/Income (\%) }\end{array}$} & \multicolumn{4}{|c|}{ Change in consumer surplus ( $€$ per annum) } & \multicolumn{4}{|c|}{$\begin{array}{c}\text { Change in consumer surplus/Income } \\
(\%)\end{array}$} \\
\hline & \multirow{2}{*}{$\begin{array}{c}\text { Vehicle } \\
\text { owners only }\end{array}$} & \multirow{2}{*}{$\begin{array}{c}\text { All } \\
\text { households }\end{array}$} & \multirow{2}{*}{$\begin{array}{c}\text { Vehicle } \\
\text { owners only }\end{array}$} & \multirow{2}{*}{$\begin{array}{c}\text { All } \\
\text { households }\end{array}$} & \multicolumn{2}{|c|}{ Vehicle owners only } & \multicolumn{2}{|c|}{ All households } & \multicolumn{2}{|c|}{ Vehicle owners only } & \multicolumn{2}{|c|}{ All households } \\
\hline & & & & & Urban & $\begin{array}{l}\text { Peri. or } \\
\text { rural }\end{array}$ & Urban & $\begin{array}{l}\text { Peri. or } \\
\text { rural }\end{array}$ & Urban & $\begin{array}{l}\text { Peri. or } \\
\text { rural }\end{array}$ & Urban & $\begin{array}{l}\text { Peri. or } \\
\text { rural }\end{array}$ \\
\hline \multicolumn{13}{|c|}{ No recycling } \\
\hline 1 & -71 & -53 & $-0.61 \%$ & $-0.50 \%$ & -60 & -84 & -38 & -72 & $-0.52 \%$ & $-0.72 \%$ & $-0.36 \%$ & $-0.68 \%$ \\
\hline 2 & -71 & -53 & $-0.39 \%$ & $-0.32 \%$ & -66 & -78 & -44 & -68 & $-0.36 \%$ & $-0.43 \%$ & $-0.26 \%$ & $-0.41 \%$ \\
\hline 3 & -79 & -68 & $-0.31 \%$ & $-0.28 \%$ & -68 & -93 & -55 & -89 & $-0.27 \%$ & $-0.37 \%$ & $-0.22 \%$ & $-0.36 \%$ \\
\hline 4 & -84 & -77 & $-0.26 \%$ & $-0.24 \%$ & -74 & -101 & -66 & -98 & $-0.23 \%$ & $-0.31 \%$ & $-0.21 \%$ & $-0.31 \%$ \\
\hline 5 & -88 & -75 & $-0.18 \%$ & $-0.16 \%$ & -79 & -114 & -65 & -111 & $-0.16 \%$ & $-0.24 \%$ & $-0.14 \%$ & $-0.24 \%$ \\
\hline All & -79 & -65 & $-0.29 \%$ & $-0.26 \%$ & -71 & -92 & -54 & -84 & $-0.26 \%$ & $-0.34 \%$ & $-0.21 \%$ & $-0.33 \%$ \\
\hline \multicolumn{13}{|c|}{ "Flat" recycling } \\
\hline 1 & -8 & 11 & $-0.07 \%$ & $0.10 \%$ & 4 & -20 & 26 & -8 & $0.03 \%$ & $-0.17 \%$ & $0.25 \%$ & $-0.08 \%$ \\
\hline 2 & -8 & 11 & $-0.04 \%$ & $0.07 \%$ & -2 & -15 & 20 & -4 & $-0.01 \%$ & $-0.08 \%$ & $0.12 \%$ & $-0.02 \%$ \\
\hline 3 & -15 & -5 & $-0.06 \%$ & $-0.02 \%$ & -4 & -30 & 9 & -25 & $-0.02 \%$ & $-0.12 \%$ & $0.04 \%$ & $-0.10 \%$ \\
\hline 4 & -20 & -13 & $-0.06 \%$ & $-0.04 \%$ & -11 & -38 & -2 & -34 & $-0.03 \%$ & $-0.12 \%$ & $-0.01 \%$ & $-0.11 \%$ \\
\hline 5 & -24 & -12 & $-0.05 \%$ & $-0.03 \%$ & -16 & -50 & -1 & -47 & $-0.03 \%$ & $-0.10 \%$ & $0.00 \%$ & $-0.10 \%$ \\
\hline All & -15 & -1 & $-0.05 \%$ & $0.00 \%$ & -7 & -28 & 10 & -20 & $-0.03 \%$ & $-0.10 \%$ & $0.04 \%$ & $-0.08 \%$ \\
\hline \multicolumn{13}{|c|}{ "Size-based" recycling } \\
\hline 1 & 5 & 19 & $0.04 \%$ & $0.18 \%$ & 14 & -5 & 29 & 4 & $0.12 \%$ & $-0.04 \%$ & $0.27 \%$ & $0.04 \%$ \\
\hline 2 & -5 & 8 & $-0.03 \%$ & $0.05 \%$ & -2 & -11 & 14 & -3 & $-0.01 \%$ & $-0.06 \%$ & $0.08 \%$ & $-0.02 \%$ \\
\hline 3 & -11 & -4 & $-0.04 \%$ & $-0.02 \%$ & -2 & -24 & 8 & -21 & $-0.01 \%$ & $-0.09 \%$ & $0.03 \%$ & $-0.09 \%$ \\
\hline 4 & -20 & -14 & $-0.06 \%$ & $-0.04 \%$ & -12 & -34 & -5 & -31 & $-0.04 \%$ & $-0.11 \%$ & $-0.02 \%$ & $-0.10 \%$ \\
\hline 5 & -27 & -16 & $-0.06 \%$ & $-0.03 \%$ & -19 & -52 & -7 & -49 & $-0.04 \%$ & $-0.11 \%$ & $-0.01 \%$ & $-0.10 \%$ \\
\hline All & -12 & -1 & $-0.04 \%$ & $0.00 \%$ & -6 & -22 & 7 & -16 & $-0.02 \%$ & $-0.08 \%$ & $0.03 \%$ & $-0.06 \%$ \\
\hline \multicolumn{13}{|c|}{ "Income-based" recycling } \\
\hline 1 & -40 & -24 & $-0.34 \%$ & $-0.23 \%$ & -42 & -39 & -20 & -30 & $-0.36 \%$ & $-0.34 \%$ & $-0.19 \%$ & $-0.28 \%$ \\
\hline 2 & -23 & -9 & $-0.13 \%$ & $-0.05 \%$ & -24 & -22 & -5 & -15 & $-0.13 \%$ & $-0.12 \%$ & $-0.03 \%$ & $-0.09 \%$ \\
\hline 3 & -11 & -3 & $-0.04 \%$ & $-0.01 \%$ & -12 & -10 & 0 & -8 & $-0.05 \%$ & $-0.04 \%$ & $0.00 \%$ & $-0.03 \%$ \\
\hline 4 & 2 & 7 & $0.01 \%$ & $0.02 \%$ & 0 & 5 & 7 & 7 & $0.00 \%$ & $0.02 \%$ & $0.02 \%$ & $0.02 \%$ \\
\hline 5 & 17 & 27 & $0.04 \%$ & $0.06 \%$ & 19 & 12 & 31 & 14 & $0.04 \%$ & $0.03 \%$ & $0.07 \%$ & $0.03 \%$ \\
\hline All & -11 & -1 & $-0.04 \%$ & $0.00 \%$ & -9 & -14 & 4 & -10 & $-0.03 \%$ & $-0.05 \%$ & $0.02 \%$ & $-0.04 \%$ \\
\hline
\end{tabular}

${ }^{\mathrm{a}}$ The tax is set to $€ 0.071$ per litre of gasoline and $€ 0.081$ per litre of diesel (2006€), and is imposed on top of existing taxes. 
Table 7: Simulation results of the "High" tax scenario

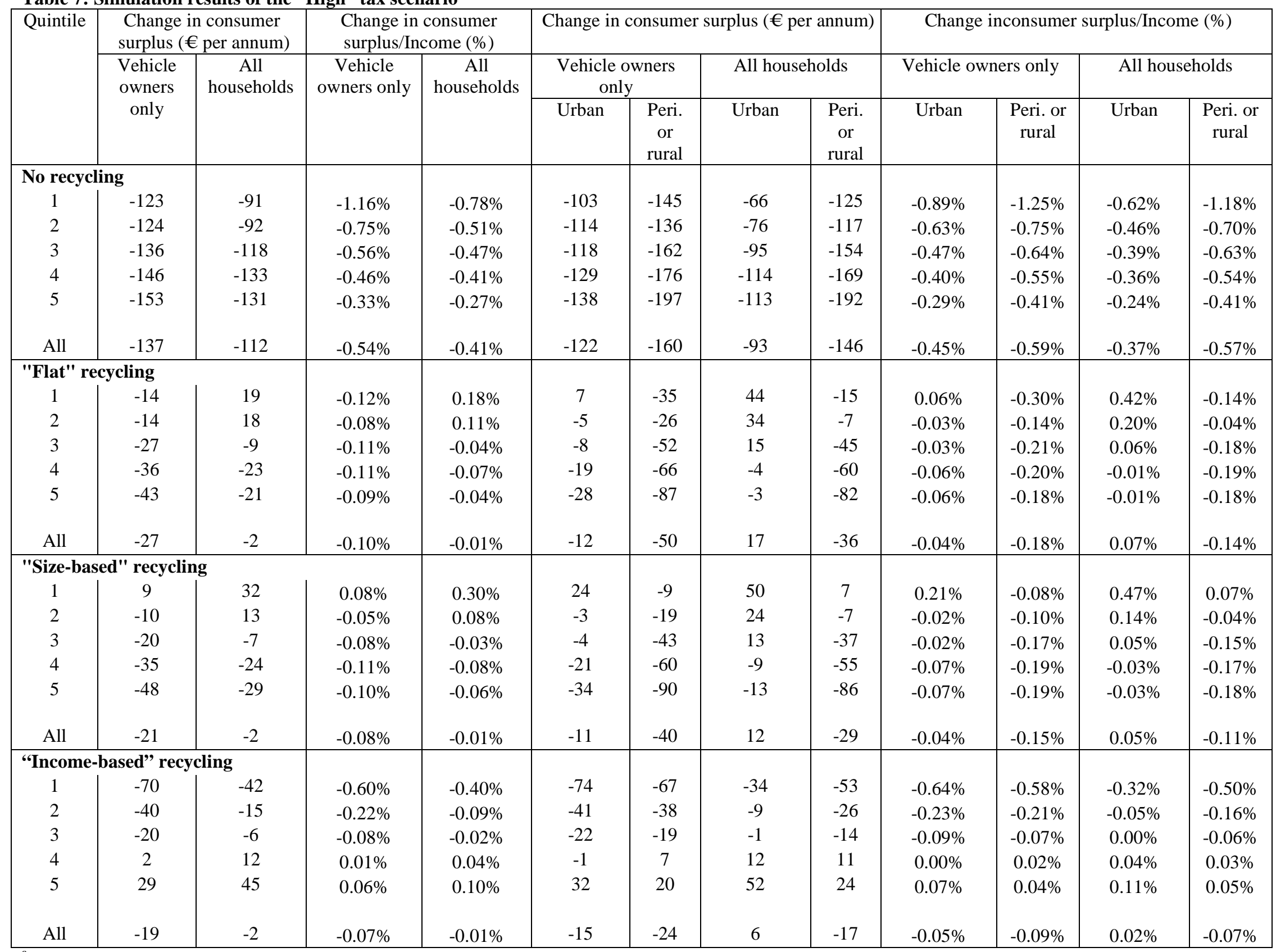

${ }^{\mathrm{a}}$ The tax is set to $€ 0.124$ per litre of gasoline and $€ 0.140$ per litre of diesel (2006€), and is imposed on top of existing taxes. 
5.3.2. Distributive impact of a carbon tax in the Paris Region considering the benefits from congestion reduction

Table 8 first gives the distribution of impacts generated by carbon pricing for the residents of the Paris Region only, without considering the benefits from congestion reduction. As expected the average welfare loss induced by the carbon tax is smaller in the Paris Region. Motorised households lose $€ 69$ on average versus $€ 79$ for the whole country. This is so because households living closer to Paris tend to drive fewer kilometres and to be more price sensitive - thanks to a better access to public transport. If non-motorised households are also considered, the average loss is $€ 45$ for those living in the Paris Region versus $€ 65$ for the whole country. Such difference reflects the fact that Paris Region residents are less dependent on cars. However, even if the magnitude of losses differs between the Paris Region and France, the distribution of losses is virtually the same.

Table 8: Simulation results of the reference scenario ${ }^{\mathrm{a}}$ for the Paris Region population only

\begin{tabular}{|c|c|c|c|c|}
\hline Quintile & \multicolumn{2}{|c|}{$\begin{array}{c}\text { Change in consumer } \\
\text { surplus (€ per annum) }\end{array}$} & \multicolumn{2}{c|}{$\begin{array}{c}\text { Change in consumer } \\
\text { surplus/Income (\%) }\end{array}$} \\
\cline { 2 - 5 } & $\begin{array}{c}\text { Vehicle } \\
\text { owners only }\end{array}$ & $\begin{array}{c}\text { All } \\
\text { households }\end{array}$ & $\begin{array}{c}\text { Vehicle } \\
\text { owners only }\end{array}$ & $\begin{array}{c}\text { All } \\
\text { households }\end{array}$ \\
\hline 1 & -66 & -37 & $-0.42 \%$ & $-0.23 \%$ \\
2 & -57 & -36 & $-0.24 \%$ & $-0.15 \%$ \\
3 & -70 & -42 & $-0.24 \%$ & $-0.14 \%$ \\
4 & -72 & -55 & $-0.19 \%$ & $-0.15 \%$ \\
5 & -76 & -54 & $-0.12 \%$ & $-0.09 \%$ \\
All & -69 & -46 & $-0.23 \%$ & $-0.15 \%$ \\
\hline
\end{tabular}

a The tax is set to $€ 0.071$ per litre of gasoline and $€ 0.081$ per litre of diesel (2006€), and is imposed on top of existing taxes.

Consider now the benefits induced by the reduction of congestion. According to our simulations, the introduction of a carbon tax of 7 cents per litre of gasoline and 8 cents per litre of diesel leads to a $1.7 \%$ reduction of total traffic in the Paris Region. ${ }^{27}$ This leads, in turn, to an average reduction in travel time of $0.4 \%$. Table 9 presents the benefits, in monetary terms, induced by the reductions in travel time.

Depending on the values of travel time considered, the carbon tax leads to average benefits of $€ 7$ to $€ 12$ a year for motorised households, and $€ 6$ to $€ 11$ if all households are

\footnotetext{
${ }^{27}$ This traffic reduction implies a reduction in $\mathrm{CO}_{2}$ emissions of some 77,000 tons a year. It represents less than $0.2 \%$ of total greenhouse gases emissions in the Region.
} 
considered. Compared to the average costs induced by the tax, i.e., $€ 69$ for motorised households and $€ 46$ for the whole population (see Table 8), the benefits induced by the congestion reduction are not negligible. They represent from $10 \%$ to $24 \%$ of average costs, depending on assumptions about VOT and the population considered.

As regards equity, Table 9 shows that the benefits clearly increase with income. This result is quite intuitive. Richer households, which drive more and have higher values of travel time, benefit more from the speed increases. However, if the benefits are expressed as a percentage of income, the poorest households gain more. Then taking into account the benefits from congestion reduction mitigates the regressivity of the fuel tax before revenue recycling.

This result is robust to the set of VOT considered. In particular, it holds using Bureau and Glachant's (2008) values where the VOT of the richest households is more than twice the VOT of the poorest. Our findings support Parry et al.'s (2007) suggestion that low-income groups may benefit more (relative to their income) from the mitigation of congestion.

Also, it is worth noting that this result follows Pearce's (2003) conclusion for environmental externalities: "overall, while the evidence is limited, the general thrust of the literature is that, for individual goods, the income elasticity of [the willingness to pay for environmental improvements] is less than unity. The recent empirical work tends to support [the] suggestion that the impression that environmental quality is an 'elitist' good is not justified. The implication for policy is that environmental policy is probably biased towards benefiting the poor rather than the rich." 
Table 9: Welfare impacts induced by the reductions in travel time

\begin{tabular}{|c|c|c|c|c|c|c|c|c|}
\hline \multirow[t]{3}{*}{ Quintile } & \multicolumn{4}{|c|}{ "Low VOT" } & \multicolumn{4}{|c|}{ "High VOT" } \\
\hline & \multicolumn{2}{|c|}{$\begin{array}{l}\text { Change in consumer } \\
\text { surplus }(€ \text { per annum) }\end{array}$} & \multicolumn{2}{|c|}{$\begin{array}{l}\text { Change in consumer } \\
\text { surplus/Income }(\% o)\end{array}$} & \multicolumn{2}{|c|}{$\begin{array}{l}\text { Change in consumer } \\
\text { surplus ( } € \text { per annum) }\end{array}$} & \multicolumn{2}{|c|}{$\begin{array}{l}\text { Change in consumer } \\
\text { surplus/Income }(\% o)\end{array}$} \\
\hline & $\begin{array}{c}\text { Vehicle } \\
\text { owners } \\
\text { only }\end{array}$ & $\begin{array}{c}\text { All } \\
\text { households }\end{array}$ & $\begin{array}{c}\text { Vehicle } \\
\text { owners } \\
\text { only }\end{array}$ & $\begin{array}{c}\text { All } \\
\text { households }\end{array}$ & $\begin{array}{c}\text { Vehicle } \\
\text { owners } \\
\text { only }\end{array}$ & $\begin{array}{c}\text { All } \\
\text { households }\end{array}$ & $\begin{array}{c}\text { Vehicle } \\
\text { owners } \\
\text { only }\end{array}$ & $\begin{array}{c}\text { All } \\
\text { households }\end{array}$ \\
\hline 1 & 4 & 3 & $0.29 \%$ & $0.27 \%$ & 11 & 9 & $0.74 \%$ & $0.67 \%$ \\
\hline 2 & 5 & 5 & $0.23 \%$ & $0.21 \%$ & 11 & 10 & $0.49 \%$ & $0.45 \%$ \\
\hline 3 & 6 & 5 & $0.20 \%$ & $0.19 \%$ & 11 & 10 & $0.38 \%$ & $0.37 \%$ \\
\hline 4 & 8 & 8 & $0.22 \%$ & $0.21 \%$ & 13 & 13 & $0.35 \%$ & $0.33 \%$ \\
\hline 5 & 9 & 9 & $0.15 \%$ & $0.14 \%$ & 13 & 12 & $0.21 \%$ & $0.20 \%$ \\
\hline All & 7 & 6 & $0.21 \%$ & $0.20 \%$ & 12 & 11 & $0.40 \%$ & $0.39 \%$ \\
\hline
\end{tabular}

Notes: Gains are induced by reductions in travel time following a 1.7\% reduction in traffic due to the introduction of a carbon tax of $€ 0.071$ per litre of gasoline and $€ 0.081$ per litre of diesel (2006€), imposed on top of existing taxes.

\section{Conclusion}

This paper analyses the distributional effects of alternative scenarios of carbon taxes on private vehicle fuels in France. The methodology is based on a car use model that is estimated using disaggregated panel data from 2003 to 2006.

We have simulated the impact of a carbon tax on car fuels of $€ 31$ per tonne of $\mathrm{CO}_{2}$, which is the official figure to be considered in France when making environmental evaluation of public policies. It was set to achieve the European objective of a $14 \%$ reduction in greenhouse gases emissions by 2020, compared to 2005 levels. It corresponds to an additional tax of around 7 euro-cents per litre of gasoline and 8 cents per litre of diesel.

According to our calculations, this tax induces an average annual loss of $€ 79$ per motorised household, $€ 65$ if all households are considered. This loss increases with income. It costs $€ 71$ per year for motorised households of the first income quintile against $€ 88$ for those of the fifth quintile. This result is driven by three main factors: the wealthiest households own more cars, drive more, and are less price-sensitive. 
Conclusions are reversed if losses are expressed in proportion to income. The poorest households lose $6.3 \%$ of their income, as compared to $1.9 \%$ for the wealthiest. The carbon tax is then regressive.

The tax impact varies also with residential location. Unsurprisingly, peri-urban and rural households lose more than urban ones, even after controlling for income. The difference is striking for the poorest households: households of quintile 1 that live in peri-urban or rural areas lose $90 \%$ more than other households of quintile 1 ( $€ 72$ versus $€ 38$ ).

However, the distributional effects of tax payments represent only one side of the problem. We also tried to measure the distributional effect of the revenues generated by the tax. We concentrated on revenue-neutral schemes where revenues are returned to households. In our simulations, the amount redistributed is $€ 64$ - for every household in the case where redistribution is uniform; on average in the case where redistribution is based on the number of equivalised persons in the household, or in the case where the tax receipts are recycled in proportion to income.

Recycling the carbon tax revenues either in equal amounts to each household or according to household size makes poorest households better off. Their net gain is about $€ 11$ to $€ 19$ per year while the wealthiest households lose around $€ 12$ to $€ 16$. Such recycled carbon taxes are then progressive. Note that this phenomenon increases with the level of carbon taxation. On the other hand, if revenues are recycled in proportion to income, only rich households stand to gain. This option is regressive. Furthermore, under whichever recycling method, urban households are net gainers while peri-urban or rural households are net losers.

An important contribution of the paper is that we consider the benefits induced by the reduction of congestion due to the introduction of the carbon tax. Accounting for those benefits mitigates the regressivity of the fuel tax before revenue recycling. Prior studies do 
not take this effect into account, thus potentially overestimating the regressivity of fuel taxation.

Some limitations in our approach deserve mention. First, although the model allows households to respond to the additional taxation by reducing the number of kilometres they drive, we do not consider potential responses in terms of changes of fleet size and/or composition. Second, we use a partial equilibrium model. A full evaluation of the carbon tax would ideally require a general equilibrium framework. Finally, we rely on a basic traffic model - a simple speed-flow relationship - to calculate the time savings induced by the carbon tax.

\section{Acknowledgments}

I wish to thank Matthieu Glachant and an anonymous referee for very detailed comments on previous drafts and for their suggestions for improvement. I am also grateful to Bruno De Borger, Jean-Charles Hourcade, Pierre Kopp, Stef Proost, Charles Raux and Eric Strobl for helpful comments, and Laurent Hivert for his help with the data. Financial support was provided by the French Ministry of Transport (PREDIT research program) and by the Ile-deFrance Region (Réseau de Recherche sur le Développement Soutenable, R2DS). The usual disclaimer applies.

\section{References}

Bento AM, Goulder LH, Jacobsen MR, von Haefen RH. Distributional and Efficiency Impacts of Increased U.S. Gasoline Taxes. American Economic Review 2009; 99 (3); 667699.

Bento AM, Goulder LH, Henry E, Jacobsen MR, von Haefen RH. Distributional and Efficiency Impacts of Gasoline Taxes: An Econometrically Based Multi-market Study. American Economic Review Papers and Proceedings 2005; 95(2); 282-287. 
Berkowitz MK, Gallini NT, Miller EJ, Wolfe RA. Disaggregate Analysis of the Demand for Gasoline. Canadian Journal of Economics 1990; 23 (2); 253-275.

Berri A. Dynamiques de la motorisation et des dépenses de transport des ménages - Analyses sur données individuelles et semi-agrégées. Ph.D. Thesis, Université de Paris 1 - Panthéon Sorbonne, France; 2005.

Blow L, Crawford I. The Distributional Effects of Taxes on Private Motoring. Commentary $\mathrm{N}^{\circ}$ 65, The Institute for Fiscal Studies, London; 1997.

Bureau B, Glachant M. Distributional effects of road pricing: Assessment of nine scenarios for Paris. Transportation Research Part A 2008 ; 42 (7) ; 994-1008.

CAS. La valeur tutélaire du carbone. Centre d'Analyse Stratégique, Rapport de la Commission présidée par Alain Quinet; 2008.

Commissariat Général du Plan. Transports : choix des investissements et coût des nuisances. Paris; 2001.

Delft. Handbook on estimation of external costs in the transport sector - Produced within the study Internalisation Measures and Policies for All external Cost of Transport (IMPACT), Version 1.1; 2008.

De Palma A, Fontan C. Choix modal et valeurs du temps en Ile-de-France. Recherche Transport Sécurité 2001; 71; 24-46.

Dubin JA, McFadden DL. An econometric analysis of residential electric appliance holdings and consumption. Econometrica 1984; 52 (2); 345- 362.

Goldberg PK. The Effects of the Corporate Average Fuel Efficiency Standards in the US. The Journal of Industrial Economics 1998; 46 (1); 1-33.

Goodwin P, Dargay J, Hanly M. Elasticities of Road Traffic and Fuel Consumption with Respect to Price and Income: A Review. Transport Reviews 2004; 24(3); 275-292.

Graham D J, Glaister S. The demand for automobile fuel: a survey of elasticities. Journal of Transport Economics and Policy 2002; 36(1); 1-26.

Hensher DA, Smith NC, Milthorpe FW, Barnard P. Dimensions of Automobile Demand: A Longitudinal Study of Household Automobile Ownership and Use. North Holland; 1992.

Mannering F, Winston C. A dynamic empirical analysis of household vehicle ownership and utilization. RAND Journal of Economics 1985; 16 (2); 213-236.

Nijman T, Verbeek M. Nonresponse in Panel Data: The Impact on Estimates of a Life Cycle Consumption Function. Journal of Applied Econometrics 1992; 7(3); 243-57.

OECD. OECD in Figures, 2006-2007 Edition; 2006. 
Parry IWH, Walls M, Harrington W. Automobile Externalities and Policies. Journal of Economic Literature 2007; 45(2); 373-399.

Pearce D. Conceptual framework for analysing the distributive impacts of environmental policies. Prepared for the OECD Environment Directorate Workshop On The Distribution of Benefits and Costs of Environmental Policies, Paris March 2003, Revised and final copy; 2003.

Poterba JM 1991. Is the Gasoline Tax Regressive? In D. Bradford (Ed), Tax Policy and the Economy 5; 1991.p. 145-164.

Røed Larsen E. Distributional Effects of Environmental Taxes on Transportation: Evidence from Engel Curves in the United States. Journal of Consumer Policy 2006; 29 (3); 301-318.

Santos G, Catchesides T. Distributional Consequences of Gasoline Taxation in the United Kingdom. Transportation Research Record 2005, 1924, 103-111.

Small KA, Verhoef TV. The Economics of Urban Transportation. London and New York: Routledge; 2007.

Train K. Qualitative Choice Analysis: Theory, Econometrics, and an Application to Automobile Demand. The MIT Press, Cambridge, MA; 1986.

UNITE. UNITE: UNIfication of accounts and marginal costs for Transport Efficiency, Final Report for Publication, Prepared for the European Commission, Fifth Framework RTD Programme; 2003.

West SE, Distributional Effects of Alternative Vehicle Pollution Control Policies. Journal of Public Economics 2004; 88(3-4); 735-57.

Wooldridge JM. Introductory Econometrics: A Modern Approach. Third Edition, South Western; 2006.

Wooldridge JM. Econometric Analysis of Cross Section and Panel Data. MIT Press Cambridge, Massachusetts - London, England; 2002. 


\section{Appendix A: More on the values of travel time used in the simulations}

This Appendix provides additional detail on the values of travel time we use in the simulations. As explained in the core of text, Bureau and Glachant (2008) and De Palma and Fontan (2001) produce substantially different levels for values of travel time. Three reasons may partly explain such difference. First, Bureau and Glachant use the 2001-2002 Global Transport Survey while De Palma and Fontan use the 1997 Global Transport Survey. Second, both papers produce values of travel time for commuters but De Palma and Fontan focus on the morning peak while Bureau and Glachant consider the whole day. Finally, both papers estimate mode choice models but specify the utility functions differently. Bureau and Glachant estimate a mode choice model that is not linear in income while the results we take from De Palma and Fontan do not include income effects. ${ }^{28}$

\footnotetext{
${ }^{28}$ In fact, De Palma and Fontan estimate several models with various specifications (Logit, Probit, Mixed Logit and a Logit with an income effect). But only the Logit and Probit are used to produce values of travel time for different income groups that we can reuse in our simulations (taking the average of the two).
} 
Appendix B: Regression results including Paris Region specific effects

\begin{tabular}{|c|c|c|}
\hline Variables & \multicolumn{2}{|c|}{$\mathrm{FE}$} \\
\hline p*ONE*PARIS & $-50,875 * *$ & $(23167)$ \\
\hline p*TWO*PARIS & $-78,738 * *$ & $(35582)$ \\
\hline p*INCOME*ONE*PARIS & 0.419 & $(0.267)$ \\
\hline p*INCOME*TWO*PARIS & 0.459 & $(0.535)$ \\
\hline $\mathrm{p}^{*} \mathrm{ONE} * \mathrm{FR}$ & $-38,364 * *$ & $(16546)$ \\
\hline $\mathrm{p} * \mathrm{TWO} * \mathrm{FR}$ & $-77,647 * * *$ & $(27416)$ \\
\hline p*INCOME*ONE*FR & $0.505^{* *}$ & $(0.204)$ \\
\hline p*INCOME*TWO*FR & 0.510 & $(0.429)$ \\
\hline TWO & $11700.8 * * *$ & $(3259.1)$ \\
\hline DOWNMARKET & -469.7 & $(1105.7)$ \\
\hline MIDRANGE & 270.2 & $(943.6)$ \\
\hline UTILITY & -1507.2 & $(1279.1)$ \\
\hline DOWN_DOWN & -603.0 & $(2955.3)$ \\
\hline DOWN_MID & 110.2 & $(2774.4)$ \\
\hline DOWN_UP & 2965.8 & $(2827.3)$ \\
\hline MID_MID & -214.6 & $(2854.0)$ \\
\hline MID_UP & 542.2 & $(3143.9)$ \\
\hline UTILITY_2V & 2118.2 & $(2825.0)$ \\
\hline NEW & $341.9 *$ & $(182.4)$ \\
\hline OLD_NEW & 153.4 & $(398.8)$ \\
\hline NEW_NEW & 3034.9 & $(2190.1)$ \\
\hline NB_ADULTS & $997.1 * *$ & $(421.9)$ \\
\hline Q2 & $-433.0 *$ & (257.3) \\
\hline Q3 & -487.3 & (297.0) \\
\hline Q4 & -483.4 & (349.7) \\
\hline Q5 & $-774.7 *$ & (449.3) \\
\hline SUBURB & -341.3 & $(1063.2)$ \\
\hline PERIURBAN & $2609.6 * *$ & $(1069.0)$ \\
\hline RURAL & $5987.4 * * *$ & (1963.8) \\
\hline ADD & $-2513.3 * * *$ & $(661.4)$ \\
\hline SEP & $1752.9 * *$ & (738.0) \\
\hline YEAR04 & -7.2 & (122.8) \\
\hline YEAR05 & -171.9 & (192.6) \\
\hline YEAR06 & $-445.2 * *$ & (221.3) \\
\hline PARIS & 1607.5 & $(2197.5)$ \\
\hline CONSTANT & $12330.0 * * *$ & (1919.5) \\
\hline Observations & & \\
\hline $\mathrm{R} 2$ & & \\
\hline
\end{tabular}

Notes: FE estimator is used. Dependent variable is KM. PARIS=1 if the household lives in the Paris Region, 0 otherwise. FR=1 if the household lives anywhere in France except the Paris Region. Robust standard errors in parentheses. $*$ indicate significance at the $10 \%$ level. ** Idem, $5 \%$. *** Idem, $1 \%$. 